\title{
IFIH1 Gene
}

National Cancer Institute

\section{Source}

National Cancer Institute. IFIH1 Gene. NCI Thesaurus. Code C119719.

This gene is involved in binding to viral ribonucleic acids. 